\title{
Taipuu taipuu vaan entä jos ei taivukaan
}

\author{
Yhdysvaltalaisen sosiologin Richard Sennettin \\ Työn uusi järjestys on hämmästyttävän ajankohtainen \\ teos. Se ilmestyi vuonna 1999, joten klassikoksi teos \\ on nuori. Sillä on kuitenkin vakiintunut sijansa uuden \\ työn kriittisenä tarkastelijana.
}

TYÖN UUSI JÄRJESTYS päätyi käsiini vuoden 2010 tienoilla sosiologian perusopintoihin kuuluneen kirjatentin vuoksi. Tapanani oli mennä yliopiston kirjastoon ja selailla tenttikirjapaketin vaihtoehtoisia teoksia. Valitsin Työn uuden järjestyksen arvatenkin siksi, että se oli ohut ja saatavilla suomeksi. Uskoisin, että valintaani vaikutti myös selkeä sisällysluettelo. Voin nähdä itseni ajattelemassa, kuinka helppoa olisi opetella ulkoa tenttiä varten päälukujen otsikot: "Ajelehtiminen", "Rutiini", ”Joustavuus" ja niin edelleen. En todellakaan aavistanut, että kirja palaisi käsiini vielä monen monta kertaa tentin jälkeen.

Työn uusi järjestys esitellään niin suomennoksen takakannessa kuin esipuheessa lajityypiltään esseenä. Sellaiseksi sitä ei välttämättä heti kuitenkaan tunnista, vaan lukija ajattelee kenties lukevansa tutkimusraporttia. Jokin kuitenkin on "pielessä": teos ei noudata perinteistä tutkimuksen raportoinnin kaavaa vaan se on kokoelma lyhyehköjä kuvauksia erilaisista kohtaamisista ja tapauksista. Sinällään ei ole poikkeuksellista,

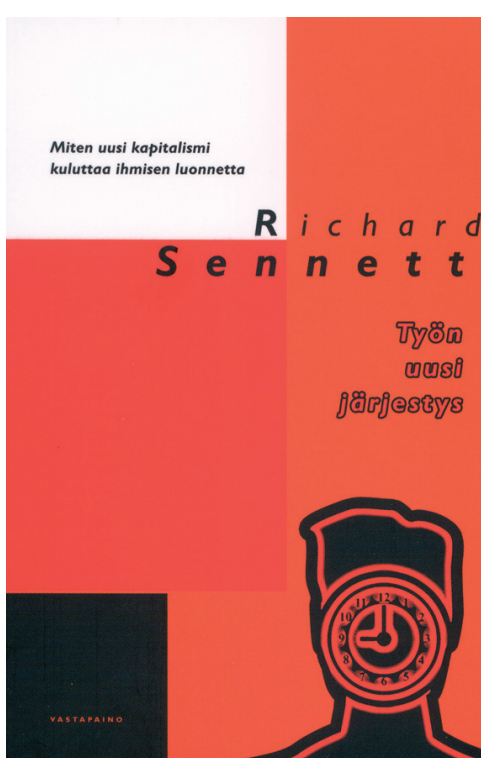

Richard Sennett kuvaa, kuinka ihmisten välinen luottamus on rapistunut ja kuinka ennakoimatonta elämästä on tullut. 


\section{SENNETT EI EDES VÄIT $\ddot{A}$}

\section{TYÖTAPAANSA TIETEELLISEKSI.}

että tutkimusraportissa esitellään tuloksia tapauksien tai analyyttisen työskentelyn avulla muodostettujen tyyppien kautta, mutta Sennett ei anna yksityiskohtaista tietoa aineistoista, niiden keräämisestä eikä varsinkaan analyysin työkaluista.

Esipuheessa kirjailija kertoo kokeilleensa "filosofisten ajatusten pitävyyttä yksittäisten ihmisten konkreettisia kokemuksia vasten”. Sennett ei edes väitä työtapaansa tieteelliseksi ja kieltäytyy perustelemasta valintaansa. Ainoa selitys on, että "ajatuksen on kestettävä tuo konkreettisen kokemuksen paino tai muuten se kuihtuu pelkäksi abstraktioksi”. Luen toteamusta kuivakkana vastauksena aikalaisdiagnoosien kohtaamaan kritiikkiin. Sosiologian piirissä on pohdittu ja kiistelty, ovatko ne teoriaa vai eivät, edes tieteellistä tietoa vai jotakin muuta. Sennett antaa lukijan tehdä omat arvostelmansa asiasta.

NIMENSÄ MUKAISESTI kirja kertoo uudenlaisesta työstä: projekteista, vaihtuvista tehtävistä ja työpaikoista. Sennett kuvaa, kuinka ihmisten välinen luottamus on rapistunut ja kuinka ennakoimatonta elämästä on tullut. Rutiinien asemesta arjen täyttävät ristiriitaiset vaatimukset. Ihmisläheisellä ja elämänmakuisella otteella kirjailija kuvaa mediatyöläisiä, leipureita ja työttömiksi jääneitä ohjelmoijia, yrittäjiä ja alanvaihtajia. He jakavat kokemuksen epävarmuudesta. Elämä on ajelehtimista, kun kiinnittymisen paikkoja on niukasti. Yksilöt taipuvat ja joustavat moninaisten vaatimusten edessä työ- ja yksityiselämissään. Kuinka kauan ihmistä voi taivutella ennen väsymistä ja murtumista?

Muistan pohtineeni kirjan äärellä katajaista suomalaista. Kataja on sitkeää, se taipuu ja taipuu, sitä voi väännellä eri asentoihin - mutta jossakin vaiheessa jopa katajan syyt väsyvät, ja käsiin jää kaksi risaista kappaletta. Analogiaa jatkaakseni: muutaman säikeen paksuinen side voi juuri ja juuri pitää kappaleita kiinni toisissaan. Tuo ohut säikeiden nippu on Sennettin teoksessa me-pronomini. Hän pohtii kokonaisen luvun verran me-pronominin puolia ja piirteitä, ja tämä on teoksen vaikeimmin ymmärrettävä luku.

Sennett argumentoi, että me vastaan muut -puhetapa ei ole ollenkaan niin hedelmällinen tapa käyttää me-pronominia kuin palauttaa keskinäinen luottamus, myöntää riippuvuutensa muista ja kantaa yhdessä epäonnistumisen taakkoja. Sennettin mielestä vahvimmat luonteet löytyivätkin irtisanottujen IBM-teknologiayrityksen koodaajien joukosta. $\mathrm{He}$ huolehtivat toisistaan ja käsittelivät irtisanomisen aiheuttamia riittämättömyyden tunteita yhdessä.

KIRJASSA ON MINÄKERTOJA - Sennett itse tai jonkinlainen tutkijahahmo, joka lainaa paljon tämän todellisesta minästä. Kirjan "tapaukset" ovat myötätuntoisella otteella kuvattuja henkilöitä, ja lähes kaikki luvut etenevät niin, että minäkertoja kohtaa jossakin arkisessa tilanteessa kiinnostavan "tyypin".

Kirja etenee jouhevasti kohtaamisesta toiseen, kaunokirjallisella taituruudella. Ensimmäinen kohtaaminen kehystetään tarinalla pitkästä lentomatkasta. Kertoja kohtaa yllättäen Rico-nimisen miehen, jonka isää hän oli haastatellut 1970-luvulla. Hän istuu Ricon vieressä ja käyttää lennon miehen haastattelemiseen. Myöhemmin palataan tuohon lentoon, kun siirrytään jälleen uuteen kohtaamiseen: "Vuosi sen jälkeen kun olin puhunut Ricon kanssa palasin bostonilaiseen leipomoon, jossa olin 25 vuotta aikaisemmin käynyt haastattelemassa leipureita kirjaani The Hidden Injuries of Class varten." Kertoja, todellinen tutkija-Sennett ja kertomusten hahmot kohtaavat siellä ja täällä, kirjallisen kudelman poimuissa. Kudelmaa pidetään koossa henkilöhahmojen välisten suhteiden avulla ja ajallisella langalla.

Esipuheessa Sennett selostaa, että jotkut henkilöt ovat todellisia, toiset yhdistelmiä monista henkilöistä. Jää epäselväksi, kuka hahmo on mitäkin. Tyypittelyyn menetelmänä perehtynyt lukija pohtii, ovatko henkilöt jonkin tietynlaisen analyysin tuottamia tyyppejä, joihin on koottu yhteen usean henkilön tai informantin kertomaa, mutta siitä ei liene kyse. Tyyppeihin tai pikemminkin kertomusten hahmoihin on liitetty mukaan esimerkiksi mediatekstejä ja tilastoja. Tapaukset lienevät jonkinlainen moniaineksinen keitos: aito kohtaaminen todellisen henkilön kanssa on fiktiolle 
KIRJAN OTE ON KRIITTINEN, JOTEN ODOTTAISI, ETT $\ddot{A}$

\section{ÄÄNEEN P $\ddot{A} \ddot{S} S I S I$ MYÖS \\ SYVÄLLE MARGINAALIIN}

\section{ASETETTU IHMINEN.}

ominaiseen tapaan kutoutunut yhteen teoreettisen ajattelun, aiemman tutkimuksen, muiden aineistojen ja filosofis-sosiologisen mielikuvituksenkin kanssa.

Tapaukset ovat puhuttelevia ja jäävät elämänmakuisuudessaan lukijan mieleen. Vielä vuosienkin jälkeen muistan työssään ja yksityiselämässään kipuilleen Ricon ja bostonilaiset leipurit, jotka heittelivät raakoja ja palaneita leipiä roskalavalle, kun temppuileva teknologia oli sekoittanut leipomon uunien paistoajat.

TEOKSEN YDIN on kiinnostava käsite, luonne (character). Termi inspiroi minua käsitteenä niin paljon, että kuljetin sitä mukanani aikuiskasvatustieteen pro gradu -tutkielmaan. En ole opiskellut filosofiaa, joten koin siihen perehtymisen haastavaksi. Selasin niin Wikipediaa kuin jo tutuksi tulleen yliopistokirjaston kirjoja. Hahmotin hiljalleen, että luonteessa on kyse hyvin keskeisestä asiasta, ihmisen olemuksesta. Käsitteeseen tutustuminen johdatti minut edelleen sellaisten sanojen kuin telos ja ethos pariin. Tuolloin kenties minuun asettui kiinnostus hyvää elämää kohtaan, ja aloin ymmärtää, kuinka aikuiskasvatustiede voi auttaa ratkomaan perustavia kysymyksiä: Mihin suunnata itsensä, elämänsä, luonteensa? Kuinka aikuinen kasvattaa itseään ja miten hän kasvaa, miten häntä kasvatetaan?

Muistan painineeni pitkään 'luonteen kuluminen’ -suomennoksen äärellä. Huikean kaunis suomenkielinen teksti sai minut pohtimaan, millainen alkuteos on. Jälleen suuntasin yliopiston kirjastoon, hain englanninkielisen painoksen ja ymmärsin heti, miten loistavaa käännöstyötä Eine ja David Kivinen olivat tehneet. Rakastan suomea, ja ehkäpä savolaisuuteni vuoksi innostun aina, kun joku käyttelee kieltä hieman tavallisuudesta poikkeavalla tavalla. Akateeminen suomi on sivistyssanojen ja käsitteiden kiemuraiseksi tekemää. Niinpä tieteellinen teksti on usein valitettavan vaikeaselkoista, vaikkei niin tarvitsisi olla.

Olen ollut onnekas saadessani opetusta ja ohjausta henkilöiltä, jotka kannustavat opiskelijoitaan suorasanaiseen ilmaisuun ja kehottavat heitä välttämään oman tieteenalan jargonia. Olen saanut lukea tekstejä, joissa käytetään suomen rikasta sanastoa luovasti. Aikuiskasvatustiede on tieteenala, jolla rajojen rikkominen on osa tieteenalan olemusta. Sille mahtuvat myös persoonallisemmat tavat kirjoittaa. Sennettin teos on inspiroinut varmasti monia taitavia tieteellisiä kirjoittajia ja valanut uskoa siihen, että myös tieteessä voi kirjoittaa tavalla, joka ei ole aivan tavanomainen.

On toki totta, että teos on monella tapaa - noh, erikoinen. Sitä ei voi antaa kandidaatintutkielmaa tekevälle opiskelijalle esimerkkinä tieteellisestä raportoinnista, eikä sitä voi ajatellakaan malliksi aineiston muodostamisesta ja analyysista. Aikuiskasvatustieteen pro gradun tekijänä olinkin vaarallisilla vesillä, kun tutkielman tärkeimmät teokset olivat tässä kirjoituksessa käsitelty Työn uusi järjestys ja aikalaisdiagnoosia kirjoittaneen Zygmunt Baumanin Notkea moderni. Ehkäpä monikaan ohjaaja ei antaisi opiskelijan lähteä tekemään tutkielmaa tällaisin eväin, mutta onneksi minä sain kokeilla.

KUTEN KULUNUT FRAASI kertoo, fyysisiltä mitoiltaan pieni kirja voi olla suuri. Olen varma, että Työn uusi järjestys on tarkoituksella pidetty tiukkana pakettina, joka ei rönsyile. Yhden tapauksen kuitenkin lisäisin teokseen. Olisin ottanut mukaan henkilön, siis "tyypin", joka edustaisi järjestelmän rattaissa murskautunutta ihmistä. Teoksen konteksti on yhdysvaltalainen yhteiskunta. Kirjan ote on kriittinen, joten olisi odotettavaa, että ääneen pääsisi myös syvälle marginaaliin asetettu ihminen. Kirjan hahmoista monet ovat hyvin heikkojen turvaverkkojen varassa, mutta entä he, jotka ovat tippuneet senkin läpi? 
Risteävät eronteot eivät tule teoksessa painokkaasti esille, ja esimerkiksi rodullistettujen henkilöiden kohtaamat erityiset sorron muodot jäävät käytännössä käsittelemättä. Siirtolaisten ja naisten ääni kuitenkin kuuluu teoksessa ainakin jossakin määrin. Naislukijana pohdin silti, miksi tapausten enemmistö on miehiä. Syy voi olla, että kirjan minä-kertoja, Sennettin tutkijahahmo tai todellinen hän itse, voi lähestyä luontevammin miehiksi olettamiaan henkilöitä ja päätyä keskustelemaan heidän kanssaan syvällisesti lyhyenkin kohtaamisen aikana.

TEOS KÄSITTELEE paljon ihmisten välisiä suhteita ja siten samalla työyhteisöjen sisäisiä suhteita. Puhe tiimeistä kuulostaa 2020-luvulla ehkä hieman vanhanaikaiselta, mutta Sennettin kuvaamat ryhmätyön varjopuolet ovat tuskin kadonneet. Näennäinen yhteisöllisyys estää huomaamasta, kuka on jäänyt piirin ulkopuolelle. Tiimeissä käydään valtapeliä ja kilpaillaan. Aiemmin työntekijässä arvostettiin sitoutumista ja luotettavuutta; työnantaja ja työkaverit tiesivät, miten hän tulee toimimaan. Nyt ennustettavuus voikin näyttäytyä joustamattomuutena.

Edes luotettavuus ei ole Sennettin mukaan yhtä tärkeää kuin aiemmin, eihän mikään ole oikeastaan kiinteää eikä pysyvää. Alati muokkautuvat ja vaihtuvat tiimit hyötyvät työntekijöistä, jotka siirtävät osaamistaan sujuvasti eivätkä takerru entiseen vaan irrottautuvat menneestä aina uudelleen ja uudelleen. Sennett käyttää termiä toimistourheilu: Työelämän pisteitä kerätään kuin pelissä ikään, mutta kukaan ei pidä pisteistä kirjaa. Jokainen peli alkaa aina alusta, vain tämän hetken tilanteella on merkitystä.
Työn uusi järjestys kestää aikaa. Se kertoo ihmisistä osana suurta kapitalistista koneistoa. Kirja muistuttaa meitä kaikkia: emme ole yksin tässä epävarmuuden ajassa, vaan voimme löytää toisemme. Presidentti Tarja Halosen elämänohjeista yksi on tiivistettynä: ”Älä sano minä, sano me." Riippuvuus muista ei ole heikkoutta vaan viisautta. Tämä korostuu aivan uudella tavalla 2020-luvulla kuin Työn uuden järjestyksen ilmestyessä. Ihmisen riippuvuussuhtaista koko elonkehään puhutaan planetaarisessa kehyksessä, ja suhteet muunlajisiin eläimiin ovat nousseet myös aikuiskasvatustieteelliseen keskusteluun.

Työn uusi järjestys saattaa olla provosoiva ja poleeminen, julistavakin. Siinä kiinnitytään yksilöihin ja yksityiskohtiin mutta maalataan suurta kuvaa suurella pensselillä. Juuri tässä piilee teoksen yksi nerokkuus: "Erityinen kertoo yleisestä" - periaatteella lukija tempaistaan mukaan taitavaan, ihmisarvoa kunnioittavaan kuvaukseen yksilön työstä ja elämästä. Perinteisen tieteellisen raportoinnin sijaan lukijalle tarjotaan välähdyksiä uudesta työstä ja rutiinien katoamisesta. Joukossa on absurdeja tuokiokuvia toimistoista ja myötätuntoa herättäviä kuvauksia aivan tavallisista ihmisistä, joiden ahdinkoon on helppo samaistua ja siten huomata, että epävarmuuden merellä ajelehtii muitakin.

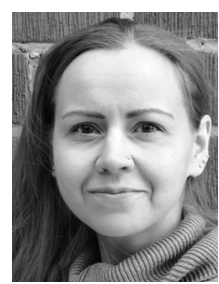

ERJA LAAKKONEN

KT, FM, vapaa tutkija, tuntiopettaja Itä-Suomen yliopisto

(D) https://orcid.org/0000-00030194-4014

\section{LÄHDE}

Sennett, R. (2002).Työn uusi järjestys. Miten uusi kapitalismi kuluttaa ihmisen luonnetta. Suomentaneet Eine Kivinen \& David Kivinen. Tampere: Vastapaino. 